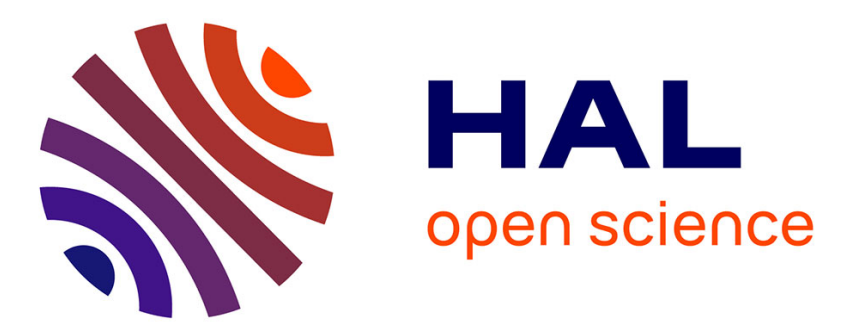

\title{
QUARTET EXCITATION IN 20Ne MAY BE SEEN THROUGH THE DECAY IN 8Be $+12 \mathrm{C}$
}

Philippe Gorodetzky, G. Rudolf, F. Scheibling, P. Chevallier

\section{To cite this version:}

Philippe Gorodetzky, G. Rudolf, F. Scheibling, P. Chevallier. QUARTET EXCITATION IN 20Ne MAY BE SEEN THROUGH THE DECAY IN 8Be + 12C. Journal de Physique Colloques, 1971, 32 (C6), pp.C6-197-C6-198. 10.1051/jphyscol:1971639 . jpa-00214857

\section{HAL Id: jpa-00214857 https://hal.science/jpa-00214857}

Submitted on 1 Jan 1971

HAL is a multi-disciplinary open access archive for the deposit and dissemination of scientific research documents, whether they are published or not. The documents may come from teaching and research institutions in France or abroad, or from public or private research centers.
L'archive ouverte pluridisciplinaire HAL, est destinée au dépôt et à la diffusion de documents scientifiques de niveau recherche, publiés ou non, émanant des établissements d'enseignement et de recherche français ou étrangers, des laboratoires publics ou privés. 


\title{
QUARTET EXCITATION IN ${ }^{20} \mathrm{Ne}$ MAY BE SEEN THROUGH THE DECAY IN ${ }^{8}$ Be $+{ }^{12} \mathrm{C}$
}

\author{
PH. GORODETZKY, G. RUDOLF, F. SCHEIBLING and P. CHEVALLIER \\ Laboratoire de Spectrométrie Nucléaire, Strasbourg-Cronenbourg
}

\begin{abstract}
Résumé. - Les résultats préliminaires de l'étude de ${ }^{19} \mathrm{~F}+\mathrm{p} \rightarrow{ }^{8} \mathrm{Be}+{ }^{12} \mathrm{C}$ et ${ }^{16} \mathrm{O}+\alpha \rightarrow{ }^{8} \mathrm{Be}+{ }^{12} \mathrm{C}$ dans la région d'excitation de $20 \mathrm{Ne} 15,3<E_{x}<18,7 \mathrm{MeV}$ semblent montrer que la plupart des niveaux trouvés sont 8 particule-4 trous et que les deux plus importantes résonances peuvent être la tête de bande du processus 12 particule- 8 trous.

Abstract. - Preliminary results of the study of ${ }^{19} \mathrm{~F}+\mathrm{p} \rightarrow{ }^{8} \mathrm{Be}+{ }^{2} \mathrm{C}$ and $16 \mathrm{O}+\alpha \rightarrow 8 \mathrm{Be}+{ }^{12} \mathrm{C}$ in the region of excitation of ${ }^{20} \mathrm{Ne} 15.3<E_{x}<18.7 \mathrm{MeV}$ show tentatively that most of the found levels are 8 particle- 4 holes, and the two biggest resonances could be the head band of 12 particle- 8 holes process.
\end{abstract}

The preliminary results described here are tentative to show that ${ }^{20} \mathrm{Ne}$ presents $8 \mathrm{p}-4 \mathrm{~h}$ and $12 \mathrm{p}-8 \mathrm{~h}$ configurations when decaying in ${ }^{8} \mathrm{Be}+{ }^{12} \mathrm{C}$.

The decay of ${ }^{20} \mathrm{Ne}$, in the energy region $15.3 \mathrm{MeV} \leqslant E_{x} \leqslant 18.7 \mathrm{MeV}$ in ${ }^{8} \mathrm{Be}+{ }^{12} \mathrm{C}$ (both in g. s.) has been measured by counting the ${ }^{8} \mathrm{Be}$ particles. This is achieved by counting the two outgoing $\alpha$-particles in fast coincidence in two counters in a special geometry [1], [2], [3].

The first reaction to be studied was ${ }^{19} \mathrm{~F}+\mathrm{p} \rightarrow{ }^{8} \mathrm{Be}$ $+{ }^{12} \mathrm{C}$ [4] (which had never been seen before). Excitation functions at $90^{\circ}$ and $120^{\circ}$ were performed and angular distributions taken at the interesting points. There are twelve clear resonances, with yield dropping to zero between them. The angular distributions become symmetric through $90^{\circ}$ at the resonance energies, indicating compound nucleus process. The cross sections at the top of the resonances go as high as $1.5 \mathrm{mb} / \mathrm{sr}$.

The second reaction was ${ }^{16} \mathrm{O}+\alpha \rightarrow{ }^{8} \mathrm{Be}+{ }^{12} \mathrm{C}$ (*) in the same region of excitation in ${ }^{20} \mathrm{Ne}$. The excitation functions show the same patterns at the same places as before and angular distributions give the same spinand parity as before. Through the help of ${ }^{19} \mathrm{~F}+\mathrm{p} \rightarrow \alpha_{0}+{ }^{16} \mathrm{O}$, recently performed, preliminary ${ }^{8} \mathrm{Be}$ widths are deduced. They comme from preliminary crude one-level fits and error bars of some $50 \%$ can be assumed.

(*) That part of the work was performed at the California Institute of Technology, supported in part by the National Science Foundation (GP-9114) and the Office of Naval Research (Nonr-220 (47)) and two of the authors (P. G. and G. R.) would like to thank Professor R. W. Kavanagh and Dr. W. K. Lin for their hospitality and cooperation.
Arima, Gillet and Ginocchio [5] give for the most probable process (220) an energy of $5.1 \mathrm{MeV}$, which experimentally comes to $7.2 \mathrm{MeV}$. (220) corresponds to weak coupling of ${ }^{24} \mathrm{Mg}$ and ${ }^{12} \mathrm{C}$ [8]. So, in the table are indicated the energies of ${ }^{24} \mathrm{Mg}$ and ${ }^{12} \mathrm{C}$ levels, and their energies plus $7.2 \mathrm{MeV}$. The sequence given by the compilation of Endt and Van der Leun [6], and Ajzenberg and Lauritsen [7] fits very well our sequence of levels.

This good concordance could come from the fact that the levels in ${ }^{24} \mathrm{Mg}$ and ${ }^{12} \mathrm{C}$ are relatively high in excitation. The concordance with the spins is not so good. Also, for most of the levels, the ${ }^{8} \mathrm{Be}$ widths are in better agreement with the $\alpha_{\pi}$ widths recently measured through ${ }^{19} \mathrm{~F}+\mathrm{p} \rightarrow \alpha_{\pi}+{ }^{16} \mathrm{O}_{6.06}$, than with the $\alpha_{0}$ widths.

But the two biggest levels cannot be explained by that process (220). The $0^{+}$at $15.44 \mathrm{MeV}$ and the $2^{+}$ at $17.22 \mathrm{MeV}$. (The $0^{+}$is very near from the threshold of the reaction, and reduced ${ }^{8} \mathrm{Be}$ width is about three times bigger.) The next process is (130) or 12 particles- 8 holes. Arima and coll. put it at $17.0 \mathrm{MeV}$, not so far from $15.44 \mathrm{MeV}$. This process is also weak coupling of ${ }^{28} \mathrm{Si}$ and ${ }^{8} \mathrm{Be}$. If ${ }^{8} \mathrm{Be}$ is considered as nearly unbound, then the sequence of levels of ${ }^{28} \mathrm{Si}$ should be the same as the sequence of levels in ${ }^{20} \mathrm{Ne}$ for (130). The first excited level in ${ }^{28} \mathrm{Si}$ is $2^{+}$at $1.779 \mathrm{MeV}$, and the difference in energy between the two levels in ${ }^{20} \mathrm{Ne}$ is $1.78 \mathrm{MeV}$. This is may be too good. The next thing to do will be to see if the $4^{+}$in ${ }^{28} \mathrm{Si}$ at $4.61 \mathrm{MeV}$ has a big correspondent in ${ }^{20} \mathrm{Ne}$ at $20.05 \mathrm{MeV}$.

The definitive results are under calculation and should be published soon. 


\begin{tabular}{|c|c|c|c|c|c|c|c|c|c|c|}
\hline $\begin{array}{c}E_{x} \\
(\mathrm{MeV})\end{array}$ & $\Gamma$ & $\Gamma_{\mathrm{Be}}$ & $\Gamma_{\alpha_{0}}$ & $\Gamma_{\alpha_{\pi}}$ & $\Gamma_{\mathrm{p}}$ & $J^{\pi}$ & $\begin{array}{c}{ }^{24} \mathrm{M} \\
{ }^{12} \mathrm{C} \\
\quad\end{array}$ & $\begin{array}{l}\text { g or } \\
\text { levels } \\
\pi\end{array}$ & $+7.2 \mathrm{MeV}$ & ${ }^{28} \mathrm{Si} \mathrm{levels}$ \\
\hline- & 一 & - & - & - & - & - & - & - & - & - \\
\hline 15.44 & 200 & 35 & 70 & 35 & 4 & $0^{+}$ & & & & $0.00^{+}$ \\
\hline 15.86 & 180 & 10 & 20 & 7 & 20 & $\begin{array}{c}2^{+} \\
\left(0^{+}\right)\left(1^{-}\right)\end{array}$ & 8.654 & $2^{+} \mathrm{Mg}$ & 15.854 & \\
\hline 16.20 & 100 & 4 & 2 & 3 & 2.5 & $\left(2^{+}\right)$ & 9.004 & $2^{+} \mathrm{Mg}$ & 16.204 & \\
\hline 16.33 & 150 & 20 & 11 & 1 & 1 & $\left(1^{-}\right)\left(2^{+}\right)$ & 9.148 & $1^{-} \mathrm{Mg}$ & 13.348 & \\
\hline 16.50 & 100 & 45 & 2 & 21 & 1 & $3^{-}$ & 9.282 & $\mathrm{Mg}$ & 16.482 & \\
\hline 16.64 & 70 & 1.5 & 30 & 3 & 4 & $\left(2^{+}\right)\left(3^{-}\right)$ & 9.456 & $\mathrm{Mg}$ & 16.656 & \\
\hline 16.74 & 80 & 2 & 25 & 2 & 1 & $3^{-}$ & 9.52 & $6^{+} \mathrm{Mg}$ & 16.72 & \\
\hline 16.90 & 100 & 20 & 3 & 3 & 7 & $1^{-}$ & 9.638 & $3^{-} \mathrm{C}$ & 16.838 & \\
\hline 16.99 & 100 & 25 & 2 & 25 & 5 & $\left(1^{-}\right)\left(4^{-}\right)$ & 9.826 & $1^{+} \mathrm{Mg}$ & 17.026 & \\
\hline 17.22 & 220 & 120 & $<10$ & $<10$ & $<5$ & $-2^{+}$ & & & & $1.7792^{+}$ \\
\hline 17.30 & 100 & 10 & 15 & 25 & 25 & $0^{+}$ & 10.10 & $\left(0^{+}\right) \mathrm{Mg}$ & 17.30 & \\
\hline 17.50 & 200 & 30 & 50 & 150 & 10 & $\left(0^{+}\right)$ & 10.3 & $\left(0^{+}\right) \mathrm{Mg}$ & 17.50 & \\
\hline 17.65 & 100 & 12 & 6 & 6 & 1 & $4^{+}$ & 10.353 & $2^{+} \mathrm{Mg}$ & 17.553 & \\
\hline 17.75 & 200 & 13 & 16 & 30 & 8 & $3^{-}$ & 10.683 & $0^{+} \mathrm{Mg}$ & 17.883 & \\
\hline 18.00 & 70 & 10 & 6 & 6 & 2 & $1^{-}$ & 10.844 & $1^{-} \mathrm{C}$ & 18.044 & \\
\hline 18.20 & 200 & 12 & 35 & 35 & 10 & $\left(2^{-}\right)\left(4^{+}\right)$ & 11.018 & $2^{+} \mathrm{Mg}$ & 18.218 & \\
\hline
\end{tabular}

All widths are in $\mathrm{keV}$. Tentative spin and parity are between parentheses. Preferred tentatives are underlined.

\section{References}

[1] Brown (R. E.), Blatr (J. S.), Bodansky (G.), Cue (N.), Kavaloski (C. D.), Phys. Rev., 1965, 138, 394.

[2] Chevallier (P.), Scheibling (F.), Goldring (G.) Plesser (I.), Sachs (M. W.), Phys. Rev., 1967, $160,827$.

[3] Jayaraman (K. S.), Holmgren (H. D.), Phys. Rev., $1968,172,1015$.

[4] Gorodetzky (Ph.), Rudolf (G.), Scheirbing (F.), Chevaluier (P.), International Conference on Nuclear Physics. Montreal, 1969.
[5] Arima (A.), Gillet (V.), Ginocchio (J.), Phys. Rev. Letters, 1970, 25, 1043.

[6] Endt (P. M.), VAN DeR LeUn (C.), Nucl. Phys., 1967, A $105,1$.

[7] Ajzenderg-Selove (F.), Lauritsen (T.), Nucl. Phys., 1968, A114, 1.

[8] Arima (A.), Horiuchi (H.) and Sebe (T.), Phys. Letters, 1967, 24, 129. 